\title{
Entrepreneurial Profile and Environmental Commitment of SMEs: A Comparative Analysis in Franceand in Tunisia
}

\author{
Jouhaina Gherib ${ }^{1}$ \& Sandrine Berger-Douce ${ }^{2}$ \\ ${ }^{1}$ Institut Supérieur de Comptabilité et d’Administration des Entreprises (ISCAE), LIGUE Laboratory, University \\ of Manouba, Tunisia \\ ${ }^{2}$ Ecole Nationale Supérieure des Mines de Saint-Etienne (ENSM-SE), Henri Fayol Institute / EPICE Department, \\ France \\ Correspondence: Sandrine Berger-Douce, Ecole Nationale Supérieure des Mines de Saint-Etienne (ENSM-SE), \\ Henri Fayol Institute / EPICE Department, France. Tel: 33-04-7742-0155. E-mail: bergerdouce@emse.fr
}

Received: August 18, 2011 Accepted: March 15, 2012 Online Published: July 1, 2012

doi: 10.5539/ibr.v5n7p1 URL: http://dx.doi.org/10.5539/ibr.v5n7p1

\begin{abstract}
A pillar of sustainable development (SD), environmental commitment is the subject of many academic studies often devoted to large enterprises located in developed countries. This article analyzes the environmental commitment of SMEs in terms of public policies in favor of SD in two national contexts, namely France and Tunisia, based on a frame of reference of entrepreneurs' profile. The deductive qualitative methodological approach is essentially based on analysis of interviews conducted in twelve SMEs in each country. The results show that the environmental commitment of SMEs and their motivations are influenced by the managers' entrepreneurial characteristics as well as their education level, degree of innovation and integration in social networks. The comparative analysis shows convergence and divergence between the French and Tunisian contexts, particularly because of public policy, a mirror image of national cultures.
\end{abstract}

Keywords: environmental commitment, entrepreneurs, SME, public policy, profile

\section{Introduction}

Environmental commitment is one of the three components of sustainable development (SD). The recent changes in the business world lead all firms of different sizes and geographical locations to feel concerned about SD in order to ensure their own sustainability.

Over the years, environmental management has become a major strategic issue (Allenby, 1999; Boiral, 2007), but it remains marginal and poorly documented in the context of SMEs. However, among the economic actors, SMEs which represent the majority of companies in the world (Levratto, 2009) are significant sources of national wealth, but also of potential harm to the natural environment. They have therefore a legitimate active role to play in SD.

Aware of the issue at stake, several countries including France and Tunisia strengthened their regulatory instruments. They also implemented incentive public policies and awareness raising campaigns conducted by the regional authorities, governmental and supranational organizations. Hence, in France, where the landscape of SMEs is largely dominated by small and very small enterprises, the Green New Deal resulting from the Grenelle Environment Forum of October 2007 will affect all economic sectors as well as French entrepreneurs in the near future. In the economic context of Tunisia, large enterprises are marginal since $99.02 \%$ of enterprises in the country employ less than 200 workers (INS, 2005). Incentive public environmental policies are explicitly directed towards SMEs because of their weight, but also their weaknesses in a globalized world.

Broadly, environmental commitment seems to move towards an increased awareness reflected in a more apparent integration of ecological principles in the management practices of SMEs (ADEME, 2009). Despite this tendency and significant public resources devoted to raising awareness and encouraging corporate environmental commitment, until the early 2000s, most SMEs did not have organized practices (Madsen \& Ulhoi, 1996; Spence et al., 1998). Difficulties persist, particularly SMEs' poor resources (Gunningham et al., 1997; Spence et al., 1998) and the chronic lack of information (Allenby, 1999; Clarck, 2000). Voluntary processes initiated by SMEs generally meet little success (Madsen \& Ulhoi, 1996). SME managers are alleged to be poorly motivated to go 
beyond legal requirements (Greening \& Gray, 1994; Russo \& Fouts, 1997). The conditions of effectiveness of public policies in favor of environmental commitment of SMEs can legitimately be questioned in both North and South economic contexts to ensure a sustainable active commitment of the economic world to SD (Palpacuer et al., 2010). Answering this question involves the realization of theoretically based and comparative studies of environmental strategies in the specific environment of SMEs and of their explanatory factors in different, though comparable, cultural and institutional contexts.

North-South comparative studies are needed because they help build a solid theory of sustainable entrepreneurship, taking into account the influence of contextual dimensions by exploring the universal and the contingent shares in SME practices related to SD to better target them and support them in this movement.

Several previous studies have speculated about the influence of entrepreneurial variables on SME commitment to SD (Kuhndt et al., 2004; Hemingway, 2005; Spence et al., 2007b). While some practices and certifications can lead to denaturing SMEs (Torrès, 2003), the decisions taken within these enterprises often remain personalized, reflecting the manager's logic of action. At the same time, authors such as Scholtens and Dam (2007) or Westerman et al. (2007) showed that the commitment to a policy of SD or corporate social responsibility (CSR) was dependent on the national culture. However most studies (Bondy et al., 2004; Kaptein, 2004) covered (often large) enterprises of industrialized countries. Less frequently, researchers focused on emerging countries such as Melé et al. (2006), but research into the appropriation of SD by SMEs in developing countries remains very marginal and not well known (Luetkenhorst, 2004). Even if these countries do not constitute a homogeneous group (Torrès, 2001), many of these contexts are difficult for SMEs, adding to the challenge of small size, that of the development level of the country and low living standards and environmental awareness of local consumers. In the absence of institutional incentives, there is a lack of support by businesses to CSR values and hence, a limitation or an absence of environmental practices in companies often confined to relations of sponsorship and philanthropy (Jamali \& Mirshak, 2007). The main factors favoring CSR are the values and beliefs of the manager, the search for legitimacy and belonging to a committed multinational company (Gherib et al., 2009). Rice (2006) in turn shows the role played by the individual values promoted by Islam in Egypt, to promote environmental causes of citizens.

From a North-South comparative perspective and primarily based on entrepreneurial theory, our research question concerns the link between environmental commitment of SMEs and the profile of their owner-managers. It takes place in two entrepreneurial situations that are different but historically and economically related and yet previously explored in the field of environmental commitment of SMEs, namely France and Tunisia.

The second section of the article presents the theoretical framework and outline of the research through a synthesis of previous studies. We specify, in the third section, the research methods and empirical fields in their context. Our findings are presented and analyzed by country in the fourth section, before being compared and discussed in the fifth section.

\section{Theoretical Background}

\subsection{Summary of Previous Studies}

Due to the emerging and complex character of the issue of SD ownership by enterprises, tensions, both at the level of objectives and that of the concept's content still exist (Lauriol, 2004). This doctrinal weakness associated with the difficult operationalization diminishes the rigor of the conducted research in the absence of theoretical background and of systematic specification of the content of the constructs used by researchers (Déjean \& Gond, 2002; Kolk \& Mauser, 2002). Therefore, previous studies were often focused on the explanatory factors. Hence, the concept of SMEs' commitment was rarely challenged and operationalized in a frontal way. However, unlike large enterprises, which showtheir commitments, SMEs have more discreet and less formalized practices (Lapointe \& Gendron, 2004; Berger-Douce, 2006). Some SMEs "are achieving SD unknowingly." (CBSR, 2003). Consequently, it is necessary to specify the definition of corporate environmental commitment to SMEs (Spence et al., 2007a). In this article, we report the findings of previous studies on strategies and dimensions of environmental commitment (2.1.1) as well as the factors explaining this commitment (2.1.2).

\subsubsection{Strategies and Dimensions of Environmental Commitment of SMEs}

Environmental commitment is subject to extensive research aimed at identifying environmental strategies since the late 1980s (Kolk \& Mauser, 2002). The analysis of these different models shows on the one hand, the strong heterogeneity of the terms used by authors to describe the environmental strategies (defensive, proactive, reactive, preventive, marginal, ecological, etc.) and on the other hand the dominance of purely conceptual models. These strategies are presented either as a continuum (Hunt \& Auster, 1990; Fischer \& Schot, 1993; 
Shrivastava, 1995; Gendron, 2004), or as typologies (Steger, 1988; Rondinelli \& Vastag, 1996; Brockhoff et al., 1999; Bellini, 2003; Martinet \& Reynaud, 2004). These different models are rich and interesting, but they do not take into account the specificities of SMEs, unlike the research conducted by Berger-Douce (2006) and Marchesnay (2009) that explicitly and respectively addresses SME and very small enterprises.

Alongside this typological work, researchers have focused on dimensions of the enterprise's environmental commitment on the basis of corporate practices. Hence, Spence et al. (2007a) propose a three-dimensional operationalization of the construct "commitment of SMEs to SD"retaining $1 /$ the formalization of practices through the adoption of standards and norms; 2 / the integration of SD principles in strategic company actions and 3 / the voluntarism of the approach and the extent to which laws and regulations are exceeded.

By separating the formalization and integration of SD principles in the strategies of the enterprise, this construct allows to report on the formal aspect of the commitment of the SMEs, while grasping its concrete implementation into business practices. It also allows, through this separation, and by emphasizing the voluntary nature of the process to seize the multiple forms of commitment other than the adoption of standards, which seems more appropriate for SMEs.

The interest of this construct is emphasized by the fact that qualitative indicators have been generated and validated through empirical research in Cameroon, Canada and Tunisia (Spence et al., 2007a; Gherib et al., 2009; Spence et al., 2011).

\subsubsection{Explanatory Factors of SMEs’ Environmental Commitment}

Several factors are pointed out in the literature to explain environmental commitment of SMEs, drawing on both the contingency theory and entrepreneurial theory.

The economic, political and socio-cultural environments in which the SME operates undoubtedly influence the decisions taken by the entrepreneur. However, resorting to entrepreneurial theory to explain SMEs' commitment to SD seems dominant because of the personalized nature of management in such firms. Organizational and environmental aspects identified in the literature are the identity (size, ownership structure, sector, location, corporate capital, cultural, social and political context, age, economic performance), the structure (technology, product / market, organization) and the company personnel (hierarchical structure, age distribution, social structures, level of qualification). (Gondran, 2001; Delchet, 2006; Spence et al., 2007b). The manager's personal characteristics that would condition his individual commitment (of affective, normative or calculated type) and consequently that of the SME to SD, would be his beliefs and values (Quairel \& Auberger, 2005; Paradas, 2006; Spence et al., 2007a, b).

\subsection{Research Framework}

\subsubsection{Methodological Approach of the Research}

Because of the emerging nature of research on environmental commitment of SMEs, and also of the existence of previous exploratory work rooted in entrepreneurial theory, this empirical research is part of a qualitative deductive approach (Bergadaà \& Nyeck, 1992). Qualitative methods offer the advantage of seeking to give meaning to empirical data in order to understand a phenomenon (Hlady-Rispal, 2002). We consider this type of methods as particularly suitable for international comparative research subject to strong requirements of contextualization because they are more likely to: "[...] respect the temporal dimension, assess local causality and formulate fruitful explanations.” (Miles \& Huberman, 1991)

Our rationale for qualitative research is deductive in the sense of Bergadaà and Nyeck (1992) insofar as the analysis is guided by a previously defined conceptual framework as recommended by Yin (2003). This deductive qualitative approach is more original and less frequently used particularly in the development of propositions, testing theories and their possible refutation (Hlady Rispal, 2002).

Yin emphasizes the role of theoretical development and the definition of research propositions before data collection as a feature distinguishing case studies from similar methods such as ethnography or the "grounded theory" which intentionally avoid formulating research propositions: "Only if you are forced to state some propositions will you move in the right direction. (...) this proposition, besides reflecting an important theoretical issue, also begins to tell you where to look for relevant evidence" (Yin, 2003).

In this research, we formulate research propositions linking the profile of the manager to the environmental commitment of the SME that we test through case studies allowing an analytical and non statistical generalization of results (Yin, 2003). 


\subsubsection{Research Questions and Propositions}

The main question raised in this research is "how and why do managers belonging to different contexts involve their SME in the environmental field?"

Previous work having shown that in SMEs, the profile of the manager significantly influences choices, the theoretical grounding of our research is the entrepreneurial theory. The latter defines the entrepreneurial phenomenon as the initiative of an organization generating value by an individual with specific characteristics (Daval et al., 2002). It postulates that the profile of the manager determines strategic decision-making including the adoption of SD practices (Kuhndt et al., 2004).

Applying this theory, we therefore seek to identify the profiles of managers which are most conducive to a high environmental commitment.

Several typologies of entrepreneurs have been pointed out in the literature. But, given the heterogeneity of the studies and because of methodological and conceptual differences inherent to the field of entrepreneurship, we choose with Daval et al. (2002) to go back to the dimensions synthesized in an integrative interpretative framework which is situated between the (predictive) model and typology "reflecting the diversity of cases of entrepreneurs, without seeking generalization, or determinism."

The grid adopted by Daval et al. (2002) separates the individual and the organizational analysis levels and considers organizational behavior as a response to the manager's expectations. The three first central categories of behavior concern the entrepreneur's profile as an individual. We find in the first category his history and inherent characteristics. This history determines the second category which includes entrepreneurial skills or character traits of the individual. These first two categories jointly condition the third category which is the nature of the entrepreneur's needs. The latter are finally expressed in terms of conscious motivations and then translated into actions. At the organizational level, two categories emerge from the analysis of the authors: the policy (or vision) and the management (actions and concrete implementation of the strategy). Contextual variables (opportunities, socio-economic variables) are involved as triggering factors, conditioning and accompanying the entrepreneurial phenomenon.

When applied to environmental commitment of the SME, the model of Daval et al. (2002) provides an explanatory conceptual model illustrated in Figure 1.

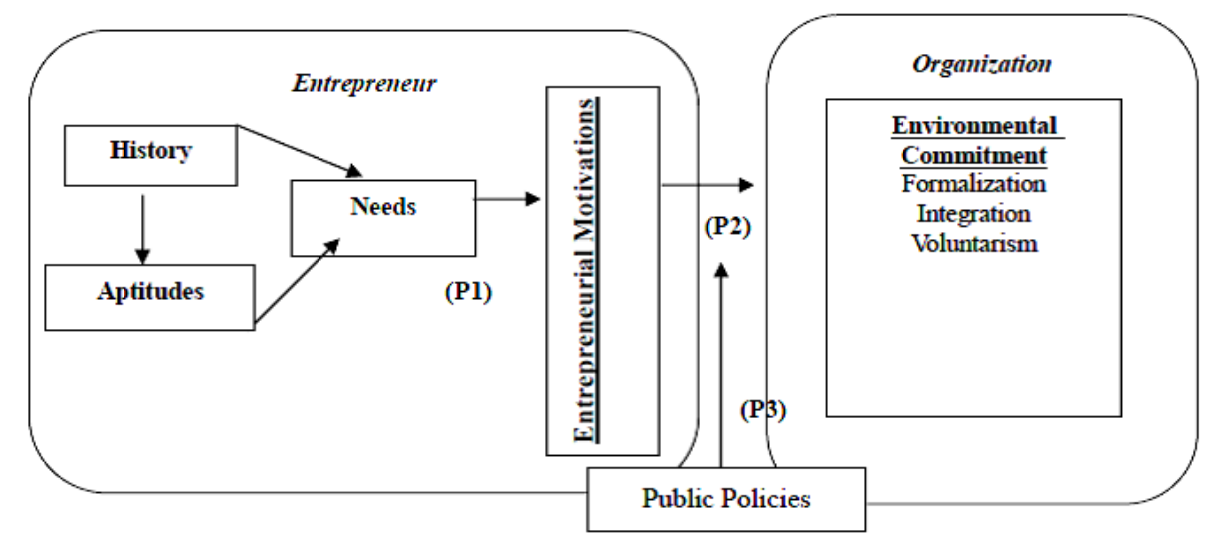

Figure 1. Manager’s Profile and Environmental Commitment

Note: Adapted from Daval et al., 2002.

The chosen model enables us to formulate the following general research propositions: "The environmental commitment of SMEs varies according to the profile of the manager."

We subdivide this general proposition into a series of propositions linking the environmental commitment of the SME to the manager's profile. Hence, "the environmental commitment of the SME would vary depending on the entrepreneurial motivations of the manager" (P2), while "the motivations would vary depending on the history, aptitudes and needs of the entrepreneur" (P1). The competitive and socio-cultural environment reflecting the implemented environmental public policies is introduced as an additional variable, supporting our comparative analysis between French and Tunisian SMEs. Hence the third research proposal (P3): "The relationship between the profile of the SME manager and environmental commitment is influenced by national environmental public policy." 
The third section of the article specifies the context of public management in France and Tunisia in terms of environmental management (3.1) before introducing the methods of data collection and analysis (3.2).

\section{Empirical Framework of the Study}

\subsection{The Context of Environmental Commitment of SMEs in France and Tunisia}

\subsubsection{The French Context}

If awareness of SD issues among French entrepreneurs increases from year to year, progress in the dissemination of information are always desirable (Gondran, 2001). Environmental management is a voluntary process launched about twenty years ago, most often following the implementation of a quality system. The National Sustainable Development Strategy (NSDS) 2003-2008 explicitly provided for facilitating access of SMEs to environmental certification. Following the Grenelle Environment Forum of 2007, AFNOR (French Standards Association) initiated in 2008 some communication activities to further sensitize SMEs to environmental issues. Based on the 2003-2008 NSDS, the 2009-2013 NSDS encourages further efforts in terms of dissemination of this public policy while making it binding to public authorities (EESC, 2010). In this regard, SD consists in working otherwise which is to say, from a perspective involving individuals, enterprises and public authorities in a collaborative approach. Developed in line with the European Strategy for Sustainable Development (ESSD), the NSSD presents mobilization of all stakeholders as essential to progress towards a sustainable development mode.

Environmental collective actions, the relevance of which has been emphasized in the literature, (Persais, 1999; Schneider-Maunoury, 2000) are implemented in France since the 1990s. More than three-quarters of the SMEs surveyed by ACFCI in 2006 reported having received support, particularly from ICC, consulting firms and AFNOR. Between 2000 and 2005, 45\% of pre diagnoses (Note 1) financially supported by ADEME were conducted as part of collective projects. Between 2000 and 2005, ADEME has financially supported the assistance of 300 midsize enterprises per year. Within three years after receiving the ADEME assistance, $88 \%$ of supported enterprises were ISO 14001certified, reflecting the relevance of this support (Chatelain, 2006).

\subsubsection{The Tunisian Context}

In Tunisia, the establishment of a free trade area in manufactured goods with the EU in 2008 has led to an extensive upgrading of the Tunisian firms since 1995. The Tunisian industry being dominated by subcontracting activities (about $70 \%$ of exports), the new world order made this type of activity subject to stiff competition, increasing dependence and vulnerability of local enterprises. New conditions, including environmental management, are becoming essential requirements to access markets for a number of exporting firms. This has led to a harmonization of the national regulatory framework with that of the European countries and to the implementation of an ambitious incentive framework to support Tunisian enterprises in their environmental commitment.

This incentive framework is part of the broader context of a national environmental policy that dates back to fifteen years ago. The state budget devotes $1.2 \%$ of GDP to environmental protection programs (MEDD, 2008) and the stated aim is to reach 500 ISO 14001 certified enterprises and to develop a Tunisian Ecolabel by 2014. The approach adopted in the economic world, since the 2000's was to multiply awareness conferences and offer financial and tax benefits to businesses. Since 2004, the diagnosis of the environmental aspect is an essential element in evaluating the enterprise applying for the Upgrade Program (PMN) in order to strengthen its competitiveness (OTED, 2007). In 2001 a program of environmental upgrading (PMNE) was launched providing expertise and grants and targeting five voluntary sectors of activity and SMEs are the main beneficiaries of the program. Applying to the PMNE is explicitly presented as a first step towards the implementation of a certified Environmental Management System. A public-private partnership for the environment was also signed in December 2006 to ensure better integration of environmental aspects within firms.

However, there are few studies analyzing (or allowing to analyze) the effectiveness of public actions conducted in favor of SD using clear and updated indicators as well as the motivations and obstacles of Tunisian enterprises in environmental commitment. Available figures highlight the small number of enterprises that are formally committed (Gherib et al., 2009). This suggests that these companies are still hesitant especially since environmental protection rank only third in their concerns (Social Consult, 2005).

\subsection{Data Analysis and Collection Methods}

Empirical research is part of a qualitative approach and has as unit of analysis the practices of SME environmental commitment, the profiles of their managers and national public policies. 
Data collection was performed by multiplying the number of contacted firms, data sources (interviews, internal and external documents in SMEs) and the interviewed actors in these enterprises. The choice of the number of SMEs was in compliance with the theoretical grounds and settled at twelve (Note 2) enterprises per country because the theoretical saturation was achieved (Mucchielli, 1991). For the sake of variety and balance (Avenier, 1989; Hlady Rispal, 2002), SMEs were identified in various but comparable business sectors in order to reflect the reality of the economic context of each country while enabling comparison of results. The study covers in both countries not only the enterprises involved in incentive processes (Note 3) in favor of environmental commitment but also non involved enterprises. All these SMEs are independent enterprises mainly oriented towards the local market.

Semi-structured interviews, which to allow a shared involvement and the control of researcher (Wacheux, 1996) have therefore been conducted with managers and, when appropriate, with environmental managers from twelve SMEs in each country. Electronic and printed documentation provided by the enterprises as well as external documentation (press articles) were also analyzed to reach a better understanding of field reality.

The interview starts with questions about the history of the enterprise's creation and its current management mode, before dealing with the understanding, sensitivity and attitude of the respondents towards the issue of SD in general and environment in particular. Subsequently, the interview seeks to mobilize the construct of Spence et al. (2011) to approach the environmental commitment of the enterprise. Then the difficulty or the easiness that they found (whether actually or potentially) is addressed to capture the manager's aptitudes, needs as well as motivations for an environmental commitment of the SME. Elements of the manager's history, such as his age, education and entrepreneurial environment are then searched, in case they did not emerge in prior phases of the interview.

Lasting from one to three hours, these interviews were recorded and then transcribed so as to preserve the significance of words and minimize misinterpretations.

Case analysis is one of the least developed and most difficult aspects to address (Yin, 2003); summary sheets were prepared to facilitate its conduct. Among the three analytic strategies proposed by Yin (2003), we chose to base our approach on the propositions formulated following the theoretical development phase of our research as a recommended and favored strategy. The authors having conducted their analysis independently compared then the results to enhance their objectivity.

This analysis strategy was based mainly on the technique of data reduction and enriched by a matrix analysis intra-site and inter-site of the main themes emerging from the interviews. As a first step, matrices were constructed for each studied case based on the previously defined themes and categories and emerging themes (Miles \& Huberman, 1991). Conceptual matrices were realized for each case in order to reach an integration of the data structure according to the predefined conceptual framework. This type of matrix is used to group two or three research questions. It shows the analyst how to proceed to conduct more detailed analysis in the form of clusters and makes it easier to realize inter-site analysis without having to resort to an overhaul (Miles \& Huberman, 1991). A summary table (meta-matrix) was finally realized grouping the synthesized and codified data of the 12 cases in each country (Table 1 ).

In each case, the intensity of environmental commitment was characterized in terms of degrees of formalization, voluntarism and integration. Each dimension is rated on a scale of 1 to 3 (low, average, high) and the synthesis of results provides the overall level of environmental commitment. A high level corresponds to a total over the three dimensions between 7 and 9 . An average level corresponds to a total between 5 and 7 and a low level to a total below 5 . According to the respondent's statements, the manager's needs are identified and classified according to the following categories: self-realization, recognition, sense of belonging, security, power. The entrepreneurial motivations for environmental commitment are categorized as 1 / emotional and depending on the manager's ethics, 2/ coercive in response to pressure from stakeholders or the quest for legitimacy or 3 / calculated resulting from the search for efficiency or competitiveness (Bansal \& Roth, 2000).

To better grasp the foreseen influence of the SME manager's profile on environmental commitment, the links between the entrepreneur's motivations and profile as well as public policies were explored in every case and in each country. After the constitution of three groups according to the degree of environmental commitment of the SME (high, average, low), the same analysis is conducted again by group and between groups in each country. Comparisons between the two countries were then performed using a comparative qualitative method recommended for international research (Wacheux, 1996). 
Table 1. Relationship between the environmental commitment and the entrepreneur's profile

\begin{tabular}{|c|c|c|c|c|c|c|c|c|c|c|c|c|c|c|}
\hline \multirow[b]{3}{*}{ 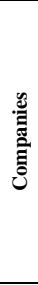 } & \multirow{2}{*}{\multicolumn{3}{|c|}{$\begin{array}{l}\text { Identification Sheet of the } \\
\text { Company }\end{array}$}} & \multirow{2}{*}{\multicolumn{4}{|c|}{$\begin{array}{c}\text { Organizational Features } \\
\text { Dimensions of Environmental } \\
\text { Management } \\
\end{array}$}} & \multicolumn{7}{|c|}{ Individual Features } \\
\hline & & & & & & & & \multicolumn{3}{|c|}{ History } & \multicolumn{2}{|c|}{ Aptitudes } & \multirow[b]{2}{*}{ zัٌ } & \multirow[b]{2}{*}{ 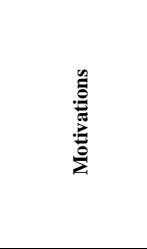 } \\
\hline & 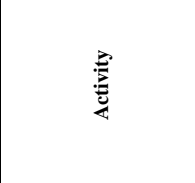 & 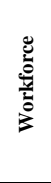 & 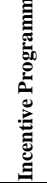 & 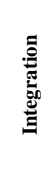 & 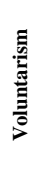 & 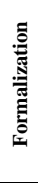 & 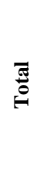 & 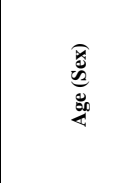 & 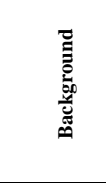 & 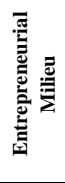 & & 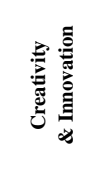 & & \\
\hline A & $\begin{array}{l}\text { Ionization by } \\
\text { electrical source }\end{array}$ & 9 & Yes & 3 & 3 & 3 & (9) & 45 years $(\mathrm{F})$ & Master & Yes & Cautious & Strong & $\begin{array}{l}\text { Security } \\
\text { Recognition } \\
\text { Autonomy } \\
\end{array}$ & AffectValues \\
\hline B & $\begin{array}{l}\text { Production of } \\
\text { pigments for paints }\end{array}$ & 42 & Yes & 2 & 2 & 3 & (7) & 57 years $(\mathrm{M})$ & Bachelor & No & Cautious & Average & $\begin{array}{l}\text { Security } \\
\text { Recognition } \\
\text { Self-achievement }\end{array}$ & $\begin{array}{l}\text { Coercion Law } \\
\text { respect }\end{array}$ \\
\hline $\mathrm{C}$ & $\begin{array}{l}\text { Cleaning of } \\
\text { industrial wastelands }\end{array}$ & 20 & No & 3 & 3 & 3 & (9) & 42 years $(\mathrm{M})$ & Master & Yes & Cautious & Strong & $\begin{array}{l}\text { Security } \\
\text { RecognitionSelf-ac } \\
\text { hievement } \\
\end{array}$ & $\begin{array}{l}\text { Affect Law } \\
\text { Respect }\end{array}$ \\
\hline $\mathrm{D}$ & \begin{tabular}{|l|} 
Pharmaceutic \\
Chemistry \\
\end{tabular} & 180 & No & 3 & 2 & 3 & (8) & 44 years $(M)$ & Master & Yes & Cautious & Strong & $\begin{array}{l}\text { Security Power } \\
\text { Recognition }\end{array}$ & $\begin{array}{l}\text { Coercion Law } \\
\text { Respect }\end{array}$ \\
\hline $\mathrm{E}$ & $\begin{array}{l}\text { Bottling of Mineral } \\
\text { Water }\end{array}$ & 65 & Yes & 3 & 1 & 3 & (7) & 58 years $(\mathrm{M})$ & Bachelor & Yes & Cautious & Average & $\begin{array}{l}\text { Security } \\
\text { Recognition } \\
\text { Self-achievement } \\
\end{array}$ & $\begin{array}{l}\text { Coercion Law } \\
\text { Respect Values }\end{array}$ \\
\hline $\mathrm{F}$ & Foundry & 49 & Yes & 2 & 2 & 2 & (6) & 47 years $(\mathrm{M})$ & $\begin{array}{l}\text { High } \\
\text { School } \\
\text { Diploma } \\
\end{array}$ & No & Cautious & Average & $\begin{array}{l}\text { Self-achievement } \\
\text { Autonomy } \\
\text { Recognition } \\
\end{array}$ & $\begin{array}{l}\text { Calculation } \\
\text { Coercion Law } \\
\text { respect } \\
\end{array}$ \\
\hline G & Food-industry & 180 & No & 2 & 2 & 1 & (5) & 55 years $(\mathrm{M})$ & Master & Yes & Cautious & Strong & $\begin{array}{l}\text { RecognitionSelf-ac } \\
\text { hievementPower }\end{array}$ & $\begin{array}{l}\text { Coercion Law } \\
\text { Respect } \\
\text { Calculation } \\
\end{array}$ \\
\hline $\mathrm{H}$ & Solar Energy & 130 & No & 2 & 3 & 1 & (6) & 56 years $(\mathrm{M})$ & Master & Yes & Proactive & Strong & $\begin{array}{l}\text { Autonomy } \\
\text { Recognition Power }\end{array}$ & $\begin{array}{l}\text { AffectValuesCal } \\
\text { culation }\end{array}$ \\
\hline I & Communication & 6 & No & 2 & 2 & 1 & (5) & 39 years $(\mathrm{M})$ & Bachelor & Yes & Cautious & Strong & $\begin{array}{l}\text { Autonomy } \\
\text { Recognition }\end{array}$ & $\begin{array}{l}\text { Affect } \\
\text { Calculation } \\
\text { Coercion }\end{array}$ \\
\hline $\mathrm{J}$ & Microcomputing & 20 & No & 1 & 1 & 1 & (3) & 40 years $(\mathrm{M})$ & Bachelor & Yes & Proactive & Weak & $\begin{array}{l}\text { Power Recognition } \\
\text { Self-achievement }\end{array}$ & $\begin{array}{l}\text { Coercion } \\
\text { Calculation }\end{array}$ \\
\hline K & Transportation & 14 & No & 1 & 1 & 1 & (3) & 52 years $(\mathrm{M})$ & $\begin{array}{l}\text { High } \\
\text { School } \\
\text { Diploma } \\
\end{array}$ & No & Cautious & Weak & $\begin{array}{l}\text { Power Autonomy } \\
\text { Recognition }\end{array}$ & $\begin{array}{l}\text { Coercion Law } \\
\text { Respect } \\
\text { Calculation } \\
\end{array}$ \\
\hline $\mathrm{L}$ & Printing House & 65 & No & 1 & 1 & 1 & (3) & 55 years $(\mathrm{M})$ & $\begin{array}{l}\text { High } \\
\text { School } \\
\text { Diploma } \\
\end{array}$ & No & Cautious & Weak & Recognition Power & $\begin{array}{l}\text { Coercion } \\
\text { Calculation }\end{array}$ \\
\hline M & Renewable Energies & 20 & Yes & 3 & 3 & 3 & (9) & 56 years $(\mathrm{M})$ & Doctorate & Yes & Cautious & Strong & $\begin{array}{l}\text { Self-achievement } \\
\text { Power Recognition }\end{array}$ & $\begin{array}{l}\text { Calculation } \\
\text { Affect (Search of } \\
\text { excellence) }\end{array}$ \\
\hline $\mathrm{N}$ & Food-Chemistry & 45 & Yes & 3 & 3 & 3 & (9) & 50 years $(\mathrm{M})$ & Master & Yes & Proactive & Strong & $\begin{array}{l}\text { Self-achievement } \\
\text { Recognition } \\
\text { Security }\end{array}$ & $\begin{array}{l}\text { Affect } \\
\text { Calculation }\end{array}$ \\
\hline $\mathrm{O}$ & Chemistry & 120 & Yes & 3 & 1 & 3 & (7) & 65 years $(M)$ & None & Yes & Cautious & Strong & $\begin{array}{l}\text { Recognition Power } \\
\text { Security }\end{array}$ & $\begin{array}{l}\text { Affect Coercion } \\
\text { Calculation(Valu } \\
\text { es, Legislations, } \\
\text { Incentives) } \\
\end{array}$ \\
\hline$P$ & Waste Management & 25 & Yes & 2 & 2 & 3 & (7) & 35 years $(\mathrm{F})$ & Master & No & Cautious & Average & $\begin{array}{l}\text { Affiliation } \\
\text { Autonomy } \\
\text { Recognition } \\
\end{array}$ & $\begin{array}{l}\text { Affect (Will to } \\
\text { conduct a } \\
\text { project) } \\
\end{array}$ \\
\hline $\mathrm{Q}$ & Leather & 80 & Yes & 2 & 2 & 3 & (7) & 39 years $(\mathrm{F})$ & Master & Yes & Proactive & Strong & $\begin{array}{l}\text { Affiliation } \\
\text { Security } \\
\text { Recognition }\end{array}$ & $\begin{array}{l}\text { Affect } \\
\text { Calculation } \\
\text { (Personal } \\
\text { Values, } \\
\text { Incentives) } \\
\end{array}$ \\
\hline $\mathrm{R}$ & Food- Industry & 8 & No & 2 & 1 & 2 & (5) & 39 years $(\mathrm{F})$ & Master & No & Proactive & Strong & $\begin{array}{l}\text { Autonomy } \\
\text { Self-achievement } \\
\text { Recognition }\end{array}$ & $\begin{array}{l}\text { Affect (Values, } \\
\text { Image) }\end{array}$ \\
\hline $\mathrm{S}$ & Solar Energy & 25 & Yes & 1 & 2 & 3 & (6) & 55 years $(\mathrm{M})$ & Bachelor & No & Cautious & Weak & $\begin{array}{l}\text { Security } \\
\text { Autonomy Power }\end{array}$ & $\begin{array}{l}\text { Calculation } \\
\text { (Incentives) }\end{array}$ \\
\hline $\mathrm{T}$ & Transportation & 160 & No & 2 & 1 & 2 & (5) & 70 years $(\mathrm{M})$ & Master & Yes & Cautious & Weak & $\begin{array}{l}\text { Power Security } \\
\text { Recognition }\end{array}$ & $\begin{array}{l}\text { Coerciion } \\
\text { Calculation } \\
\text { (Law Respect) } \\
\end{array}$ \\
\hline $\mathrm{U}$ & Building Materials & 65 & Yes & 1 & 2 & 1 & (4) & 65 years $(M)$ & None & Yes & Cautious & Weak & $\begin{array}{l}\text { Power Security } \\
\text { Reconnaissance }\end{array}$ & $\begin{array}{l}\text { Calculation } \\
\text { Coercion }\end{array}$ \\
\hline $\mathrm{V}$ & $\begin{array}{l}\text { Organization of } \\
\text { events }\end{array}$ & 4 & No & 1 & 1 & 1 & (3) & 35 years $(\mathrm{F})$ & Master & No & Cautious & Average & $\begin{array}{l}\text { Autonomye } \\
\text { Self-achievement }\end{array}$ & $\begin{array}{l}\text { Affect (Personal } \\
\text { Values) }\end{array}$ \\
\hline W & $\begin{array}{l}\text { Services to } \\
\text { enterprises }\end{array}$ & 10 & No & 1 & 1 & 1 & (3) & 40 years $(\mathrm{M})$ & Master & No & Cautious & Weak & $\begin{array}{l}\text { Security } \\
\text { Recognition }\end{array}$ & $\begin{array}{l}\text { Calculation } \\
\text { Coercion }\end{array}$ \\
\hline $\mathrm{X}$ & Printing & 25 & No & 1 & 1 & 1 & (3) & 50 years $(\mathrm{M})$ & $\begin{array}{l}\text { High } \\
\text { School } \\
\text { Diploma }\end{array}$ & No & Cautious & Weak & Security Power & $\begin{array}{l}\text { Coercion } \\
\text { Calculation }\end{array}$ \\
\hline
\end{tabular}

Note: Inspired by the grid of Daval et al., 2002. 
In the fourth section of the article, we analyze the results of the environmental commitment of SMEs in each national context (4.1 and 4.2). Elements of generalization concerning the profile of SME manager presenting a high degree of environmental commitment are then provided by country (4.3).

\section{Analysis of Results by Country}

\subsection{Environmental Commitment of French SMEs}

\subsubsection{General Description of Environmental Commitment of French SMEs}

As shown in Table 1, the French sites are part of three different competitive contexts: seven SMEs operate in the industrial sector (A, B, D, E, F, G, L), two in the field of environment (C, H) and three in services (I, J, K). Out of these SMEs, four (A, B, E, F) were involved in environmentally oriented incentive processes. In terms of environmental commitment (Spence et al., 2007a), five of these SMEs (A, B, C, D, E) present a high level. The commitment of four SMEs (F, G, H, I) is considered as average and three SMEs (J, K, L) present a low level.

The analysis of the entrepreneurial characteristics related to the history of French managers shows the importance of a high level of education (8 leaders have at least a three-year university degree) and of the presence of an entrepreneurial environment (observed in 8 SMEs out of 12). In terms of abilities, creativity and innovation are generally quite high (high in 6 SMEs and average in 3 SMEs). As regards their attitude towards risk, Interviewed French managers are overwhelmingly cautious: "The company intends to ensure its sustainability through constant dialogue with any authority about environment." (Enterprise B). Only two of them can be described as proactive.

The motivations for environmental commitment of the French managers are essentially of coercive type ( 9 out of 12 SMEs) and the compliance with the regulations strongly impregnated their statements: "Procedures existed, but were not formalized. This formalization is primarily perceived as a constraint by the operators who are rather old in the workshops" (Enterprise B). The calculated type of commitment (7 SMEs out of 12) is well ahead of emotional motivations linked to the personal values of the manager (4 SMEs out of 12). The calculated nature of environmental commitment is reflected in verbatim records such as: "We are audited five to ten times a year by our customers, which requires us to continually improve our EMS." (Enterprise D) or even: "The watchword of the Management is efficiency. So sure we can conduct environmental management, but it has to be profitable." (Enterprise F).

\subsubsection{French Managers' Profile by Level of Environmental Commitment}

Out of the three poorly committed SMEs two are operating in services (J, K) and one in industry (L). The convergence of Managers' profiles relate to their lower educational level, their poor creative capacity, their quest for power and recognition, as well as predominantly coercive and calculated motivations for the environmental commitment of their enterprises.

Three of the four managers of French SMEs with medium commitment (G, H, I) have quite similar profiles in terms of high level of education (Four-year university degree or more), the presence of an entrepreneurial environment, a cautious attitude toward risk and high creative capacity. Only the manager of the industrial SME $\mathrm{F}$ is characterized by a lower education level and the absence of an entrepreneurial environment, he is also characterized by his involvement in a collective incentive process, unlike the other three SMEs with average commitment, which can rely on their manager's profile. Regarding the motivations of the four SME managers, they are predominantly emotional for enterprise $\mathrm{H}$ (environment) and I (services) and predominantly coercive for F and G, two industrial SMEs submitted to more drastic regulatory pressures. As for their requirements, they appear rather similar because they are based on autonomy, self-realization, social recognition and power.

French SME managers with the highest commitment (A, B, C, D, E) all have more than a three-year university degree, three of which having a five-year university degree, aged between 42 and 58 and enjoy a well established entrepreneurial environment (for four out of five). With regard to their abilities, they all adopt a cautious attitude towards risk and show some creative capacity (High for (A, C, D) and average for (B, E)): "Our director, with an engineering background, crated the company in 1979. At that time, it was a real innovation to provide a solar collector serving as roofing." (Enterprise H). In terms of needs, they all seek security, social recognition and, to a lesser extent, self-realization. Their motivations are predominantly coercive (for three out of five), but predominantly emotional for the other two (A, C), while being strongly imbued with respect for law (B, C, D, E).

In France, high environmental commitment is characterized by the managers' history (P1), particularly by their level of education and the existence of an entrepreneurial environment. Creation and innovation (P1) also play an important role among French managers who demonstrate a high (A, C, D) or average (B, E) capacity for innovation. As for the attitude to risk, it is not crucial since most French managers in our study are cautious (P1). 
The analysis of the managers' needs highlights security, before (social and / or technical) recognition and self-realization (P1). Our results suggest that the motivations for environmental commitment are largely coercive in nature and, more marginally, emotional (P2). In addition, involvement in a collective incentive process seems to be a necessary but not sufficient factor to justify a high environmental commitment. In other words, even if environmental public policies play a significant role in this commitment, they can not alone explain it (P3). Indeed, out of the five highly involved French SMEs, three participated in a collective process. In contrast, none of the weakly committed SMEs undertook the experience previously.

\subsection{Environmental Commitment of Tunisian SMEs}

\subsubsection{General Description of Environmental Commitment of Tunisian SMEs}

The Tunisian sites (Table 1) belong to three different competitive contexts: environment (M, P, S), industry (N, O, $\mathrm{Q}, \mathrm{R}, \mathrm{U}, \mathrm{X})$ and services $(\mathrm{T}, \mathrm{V}, \mathrm{W})$. Seven SMEs were involved in programs favoring environmental commitment either for the creation of the business (M, P, S) or for its environmental upgrade (N, O, Q, U). Out of the 12 SMEs, five present a high commitment level (M, N, O, P, Q). The three following SMEs are moderately committed (R, S, T), while the remaining four present a low commitment level (U, V, W, X).

The studied Tunisian SMEs present a balance in terms of the age of the decision maker (5 entrepreneurs are less than 40 years and three are over 65). The educational level is high particularly among young entrepreneurs (6 managers have more than a 4-year university degree). Four of the analyzed SMES are managed by women. We note the importance of the manager's entrepreneurial environment and his integration in the network in 6 SMEs. As for abilities, creativity in the studied SMEs is limited, compared with their French counterparts, with 7 moderately or strongly innovative SMEs: "We consistently seek new products, I was ahead of my time, we have transformed the Tunisian habits." (enterprise N). The attitude to risk is mainly reluctant since 9 out of the 12 encountered managers make cautious statements: "There are opportunities, the market is growing, but I also go ahead." (enterprise P). Environmental commitment corresponds to an adventure or to actual risk taking only for enterprises $\mathrm{T}$ and $\mathrm{N}$, which attack new markets with new products, integrating social and environmental criteria in their choices.

The analysis of the needs of entrepreneurs shows they are varied. The young enterprises ran by managers who are less than forty years $(\mathrm{P}, \mathrm{R}, \mathrm{V})$, were created to satisfy the need for autonomy and self-realization to which environmental commitment contributes "I felt that I could not progress in my previous job, now I earn less [...] but I do things the way I want, I participate in my own way to make things better." (enterprise R). The enterprises created during the 70s and 80s and managed by the founder $(\mathrm{N}, \mathrm{O}, \mathrm{U}, \mathrm{X})$ seem to respond to needs of power, recognition and security. The last category concerns the entrepreneurs who, after an experience in the Tunisian administration have created, for purposes of security and power, companies in new sectors encouraged by the state such as environment (M, S) or private transport (T). Enterprises Q and W are exceptions because the first is managed by an heir who seeks a sense of belonging and security and the second was created as a source of income.

The selected sites exporting little in general, the motivations for environmental commitment in the twelve Tunisian SMEs are rarely coercive. They engage primarily in environmental actions driven by the manager's will and / or state incentives: "I have always wanted my company to be at the forefront of innovation, that is what SD is about... in addition, the state helps......" (Enterprise $\mathrm{O}$ ).

\subsubsection{Tunisian Managers' Profile by Level of Environmental Commitment}

The managers' profiles in SMEs with low commitment present very few common features that would link them or differentiate them from other more committed enterprises. Only the calculated and coercive motivations are common to the SMEs $\mathrm{W}$ and $\mathrm{X}$.

SMEs with medium commitment belong to three competitive contexts. Their entrepreneurial motivations are various. Enterprises S and T manage their SMEs according to a managerial approach and try to manage risk "penalties must be avoided." (Enterprise T). Their degree of creativity is however limited "what's the point of proposing something else, if this was worth it, we would be more numerous (in the sector)" (Enterprise S). Enterprise $\mathrm{R}$ is in a different situation since it is managed according to the entrepreneurial approach by a young woman badly inserted into professional networks, but with high creativity and quest for singularity: "Iwant to be part of those who change things." The commitment of the SME is however low due to a lack of formalization and of resources, particularly human resources. We can assert thus, that moderately committed SMEs are: 1/ small structures that are convinced, but poorly integrated in networks and lacking information and resources and 
2/ SMEs that are involved by the nature of their business (polluting or environment) but which scarcely go beyond the law and the practices of competitors. They are responsive and proceed by successive adjustments.

Among the SMEs which are strongly committed and which operate in various sectors, the motivations are in 4 enterprises out of $5(\mathrm{M}, \mathrm{N}, \mathrm{O}, \mathrm{Q})$ of emotional and calculated nature. This combination of motivations does not exist in SMEs with medium or low commitment. The stories of managers are different. The common feature for strongly committed SMEs in both contexts (environment and industry) seems to be the presence of an entrepreneurial environment and a connection to professional networks for four SMEs. Among the capabilities, creativity is never low in this group of SMEs unlike the other two. The quest for power is also not an essential need that determines the behavior of managers, who primarily look for recognition, sense of belonging or self-realization.

A strong environmental commitment seems to be associated in Tunisia with innovating managers who are personally aware of environmental issues but with different profiles: 1 / the founder of enterprises dating back to more than 20 years, highly integrated in professional networks or $2 /$ the new entrepreneur presenting a high educational level and characterized by autonomy, recognition or a sense of belonging. Investing in SD is considered by enterprises' managers adopting an entrepreneurial approach as an opportunity that can provide leadership and secure a head start on competitors. It is therefore pursued for the purpose of recognition and self-realization (P1). It is considered by entrepreneurs as a set of constraints or high-risk activities to be minimized and followed for security reasons (P1). Motivations for environmental commitment are on an equal stand emotional and calculated (P2). Participation to incentive programs involves all highly committed enterprises and also enterprises with low commitment. It could hence respond to financial and political reasons. Therefore, involvement in the incentive process represents an important indicator of the environmental commitment of Tunisian SMEs of this study (P3), but it can lead to a real environmental commitment only if the entrepreneur is convinced.

The fifth section of the article discusses the relationship between the environmental commitment of the SME and the profile of its manager in an international comparative perspective.

\section{Discussion of Results}

Based on the comparison between the profiles of SME managers that are highly committed in France and Tunisia, our results are discussed in terms of similarities (5.1) and differences (5.2) between the two national contexts.

\subsection{Similarity of Results between French and Tunisian Managers}

If we compare the profiles of French and Tunisian managers with a high level of commitment, few elements are really different, which calls into question many previous conclusions regarding the influence of national culture (P3), especially when public policies are comparable and the educational level of managers is high, as is the case in this research.

Thus, the relational network and the presence of an entrepreneurial environment appear also important to allow the entrepreneur access to information and resources and to encourage his commitment from an environmental perspective (P1). This is consistent with the idea of the importance of "community, extended family, clan and networks" in both contexts (Marchesnay et al., 2006). However, the presence of an entrepreneurial environment is not totally discriminating: $\mathrm{B}$ (in France) and P (Tunisia) do not receive such support and have yet implemented important environmental practices. Similarly, creativity and innovation (P1) appear to favor a high level of environmental commitment: the concerned SMEs in both countries were identified as playing this card moderately (B, E, P) or highly (A, C, D, M, N, O, Q). This confirms previous studies that present entrepreneurial orientation as a prerequisite for the commitment of SMEs in SD (Spence et al., 2007a, b). Indeed, in the absence of strong pressure from stakeholders and / or dissemination of responsible practices among competitors, environmental commitment can be considered as a form of innovation. It requires organizational changes that proactive and visionary entrepreneurs face more easily than others (Portugal et Yulk, 1994; Shrivastava, 1994). Moreover, a high educational level of the manager (P1) (even if does not explain alone a high commitment) could constitute an indication in favor of a high environmental commitment in both countries, the only exception being the self-taught manager of enterprise $\mathrm{N}$. This result is hardly surprising since the higher level of education is supposed to allow the acquisition of information research methods on various topics and the dissemination of universal managerial practices. However, caution is advised because of the relatively high level of education in the surveyed SMEs.

While some authors call for challenging the cliché according to which "the Mediterranean area is reluctant to entrepreneurship," (Marchesnay et al., 2006), the fields of investigation selected for our study appear to have 
common characteristics reflecting weak entrepreneurial tradition (Zghal, 2002; Fayolle \& Hernandez, 2008). Both countries are characterized by the presence of a welfare state that has implemented incentive schemes for several years and by SME managers showing a very cautious attitude towards risk. Among the most committed SMEs in both countries there is a majority of enterprises that participated in an incentive process initiated by public authorities. In contrast, only one poorly committed SME received an environment-oriented support in the framework of environmental public policy. Therefore we consider as legitimate to emphasize the need to keep these incentive schemes that are likely to play a catalytic role in environmental processes among SMEs (P3). However, in the absence of a universal panacea, these policies are only one the mechanisms of environmental commitment of these economic actors in view of their specific features particularly in terms of management customization. Hence, emerges the importance of questioning the influence of the manager's profile on the commitment of SMEs. Considering the global phenomenon of SD, the calculated attitude in environmental commitment seems important in both contexts (seven citations in France and nine citations in Tunisia) (P2). Even if it is not enough to motivate a manager, it can contribute effectively and hardly to his commitment. This calculated commitment may lead to a risk of customer loss, fear of paying fines, but more cynically, to an opportunity to benefit from government subsidies or political support. However, this opportunistic approach alone seems insufficient to trigger a process of high commitment among the managers of both countries.

\subsection{Divergence of Results between French and Tunisian Managers}

Some differences in behavior towards environment however appear between French and Tunisian entrepreneurs.

The needs of SME managers differ according to the national context. While the five strongly committed managers of French SMEs primarily seek security (before social recognition and self-realization), their Tunisian counterparts seem more eclectic in their choices. Hence, the need for security is less frequently cited than the sense of belonging, recognition and self-realization. This hierarchy of needs, added to the importance of the entrepreneurial environment as explanatory factors of the commitment of Tunisian SMEs confirms the very important role of the managers' social capital (particularly founders) and of the privileges pertaining thereto in the creation of enterprises and their competitiveness at the expense of more tangible and reproducible resources (Benhassine, 2009).

A divergence in the motivations of SMEs in both contexts is also visible. Indeed, despite the harmonization of legal frameworks between the two countries. French managers evoke particularly compliance with increasingly binding regulations, highlighting a significant coercive aspect emphasized in the 2009-2013 NSDS, in their statements. Tunisian managers report more about their environmental commitment in terms of affect but often along with the calculated incentive, which, does not imply a higher sensitivity to environmental concerns. It would be the result of a combination of the manager's long-term vision and the perceived absence of obligation whether social or legal. The present low commitment to SD values of the Tunisian civil society as well as the lack of resources available to the Tunisian Administration to conduct a rigorous control on enforcement of laws by entrepreneurs in Tunisia (OTED, 2007) lead to this feeling of lack of obligation among some of the encountered Tunisian entrepreneurs.

Beyond national institutional frameworks, this difference needs to be informed by the impact of the national culture on management of organizations. According to Zghal (2002), Tunisian entrepreneurs tend to tolerate uncertainty, which is expressed by a relative lack of written rules and procedures, making enforcement problematic and difficult to reconcile with formalized practices. Environmental commitment in the Tunisian SMEs of this research covered by our research is not of normative nature, since it does not correspond to a pressing social demand that is supported by the collectivist dimension of arabic societies as defined by Hofstede (1980). From this perspective, French managers, strongly marked by the seal of individualism, would be inclined to commit themselves to environment, primarily, under coercion.

Taking advantage of incentive public policy, entrepreneurs demonstrate a calculated commitment in both countries. However, among the selected enterprises, those adhering to incentive programs are more numerous in Tunisia. But this does not entail higher environmental commitment. This could be the translation of a systematic adherence "in order to ingratiate themselves" (Hibou, 2005) combined with a certain distrust vis-à-vis the actions taken because of "the risk of collusion between political rhetoric and advocated economic measures" (Zghal, 2002). These incentive programs, have thus been interpreted as "a control process [...] as a new expression of the relationship between companies and the central authority, formalized in administrative and financial terms" (Hibou, 2005). The efficiency of these programs is also often criticized because of administrative delays and difficulties in obtaining subsidies. Like in the French context, the incentive mechanisms are largely unknown by SME managers. Hence, the pervasiveness of informal culture and of the 
influence of networks in Tunisia (P3) leads to large information asymmetries between economic actors, a phenomenon that tends to penalize young entrepreneurs less integrated than seniors in the business community.

\section{Conclusion}

This deductive qualitative research analyzed environmental commitment of SMEs in France and in Tunisia. It is part of the comparative studies between North and South countries within a global context characterized by increasingly present public policies focused on SD. Based on the entrepreneurial theory, our analysis focused on the relationship between environmental commitment of the SME and the profile of its manager and was enhanced by the analysis of the influence of environmental public policy understood as a reflection of national culture.

Our results suggest that environmental commitment of SMEs varies depending on the manager's entrepreneurial characteristic features and, more particularly, on his profile. The constituent elements of this profile (history, aptitudes and needs of the manager) (P1) seem likely to guide the manager towards an environmental commitment of varying intensity according to his motivations (P2) and the implemented environmental public policies (P3). The analysis of similarities suggests that if the SME manager has a profile characterized by a high educational level, an expanded relational network and a strong capacity for innovation and creativity associated with high needs for security and self-realization, then the environmental commitment of his enterprise is likely to be high. The analysis also suggests that if a commitment of calculated type is common to both studied contexts, the differences are nevertheless perceptible. Thus, in a highly regulated environment (like France), the SME manager is submitted to social and institutional pressure which are likely to lead to a commitment of normative type. In a less coercive environment (such as Tunisia), the calculated commitment of the manager would, in turn, be associated with a greater emotional dimension. It also appears that even in the presence of a significant incentive, asymmetric information among economic actors and a lack of targeting beneficiaries can result in a lack of confidence in public policy despite the costs borne by the State. The environmental commitment of SME managers fully inserted into the networks, but not convinced by the environmental dimension, would thus be limited to ad hoc and opportunistic adherence to the proposed incentive programs. It would not result in a formalized, voluntary and integrated environmental management, which is likely to reduce the effectiveness of these programs. In other words, the public environmental policies whether coercive or incentive, appear as potential catalysts of environmental commitment of SMEs, but can in no way change alone the practices of SME managers.

A limitation of this comparative study concerns the number of analyzed enterprises, and their diversity in terms of size. This does not allow a statistical generalization of the results to the SME population. But the adopted approach allows an analytic generalization (Yin, 2002) by validating theoretically based research propositions and allows us to suggest the trends to be confirmed or refuted by future research. Hence, the quantitative analysis of representative samples of SMEs in both countries would be useful to confirm or refute these initial results statistically. Furthermore, our results are largely based on the interpretation of speech, which implies a risk of social desirability bias.

On a theoretical level, the importance of the influence of manager's profile (and his entrepreneurial environment) on the environmental commitment of the SME, highlighted in our study, invites to expand the conceptual framework used. It allows to resort to the social capital theory and to the notion of proximity (Torrès, 2003) for a better understanding of the studied phenomenon from a perspective aiming at reconciling global and local issues. From a managerial point of view, this analysis suggests to consider and question the relevance of procedures of awareness and support of SME managers in their environmental commitment. Indeed, the transposition of proven methods in a socio-economic context, if taken alone, cannot be considered as a sufficient guarantee to convince a significant number of managers. In the context of globalization often experienced as a threat by SME managers, recommendations common to both contexts can be proposed to public authorities. We consider, stressing the need to inform these economic actors about the opportunities related to a potential environmental commitment, as crucial. A successful dissemination of information should as a priority target entrepreneurs demonstrating a spirit of innovation and already sensitized by their involvement in managers' associations.

\section{References}

ADEME. (2009). L'environnement et la maîtrise de l'énergie dans les PME-TPE. March.

Allenby, B. R. (1999). Industrial Ecology: Policy Framework and Implementation. Prentice Hall.

Avenier, M. J. (1989). Méthodes de terrain et recherche en management stratégique. Economies et Sociétés, Sciences de Gestion, 14, 199-218. 
Bansal, P., \& Roth, K. (2000). Why companies go green: a model of ecological responsiveness. Academy of Management Journal, 43(4), 717-736. http://dx.doi.org/10.2307/1556363

Bellini, B. (2003). Un nouvel enjeu pour l'entreprise: la prise en compte de la protection de l'environnement dans son management - Etat des lieux et perspectives, Atelier Développement Durable de l'AIMS, Angers, 15 May.

Ben Slama, M. (2002). Contraintes de croissance et perspectives d'avenir in La Tunisie d'un siècle à l'autre. Beit al Hikma, 151-173.

Benhassine, N. (2009). From Privilege to Competition: Unlocking Private-led Growth in the Middle East and North Africa. Washington DC: Banque Mondiale.

Bergadaà, M., \& Nyeck, S. (1992). Recherches en marketing: un état des controverses. Recherches et Applications en Marketing, 7(3), 23-44.

Berger-Douce, S. (2006). Les enjeux stratégiques de l'engagement environnemental des petites entreprises. Gestion 2000, 1, 171-188.

Berger-Douce, S. (2007). Le management environnemental des PME rentables: Une étude exploratoire en France. Revue Internationale PME, 20(3-4), 165-190.

Berger-Douce, S. (2010). L'engagement environnemental des PME familiales. Gestion 2000, 5(10), 49-63.

Boiral, O. (2007). Environnement et Gestion - De la prévention à la mobilisation. Québec: Les Presses de l’Université Laval.

Bondy, K., Matten, D., \& Moon, J. (2004). The Adoption of Voluntary Codes of Conduct in MNCs: A Three Country Comparative Study. Business and Society Review, 109(4), 449-477. http://dx.doi.org/10.1111/j.0045-3609.2004.00205.x

Brockhoff, K., Chakrabarti, A. K., \& Kirchgeorg, M. (1999). Corporate strategies in environmental management. Research Technology Management, July-August, 26-30.

CBSR (Canadian Business for Social Responsibility). (2003). Engaging Small Business in Corporate Social Responsibility.Vancouver.

CESE. (2010). La stratégie nationale de développement durable 2009-2013. Avis du Conseil économique, social et environnemental by P. Le Clézio, 3rd February.

Chatelain, F. (2006). Le management environnemental en France: comment évaluer les pollutions évitées? Conference on 30th November (Pollutec).

Clarck, G. (2000). Developing Better Systems for Communications, Environmental Best Practices in Small Business. In R. Hillary (Ed.), Small and Medium-Sized Enterprises and the Environment. Business Imperatives, Greenleaf Publishing.

D’Amboise, G., \& Audet, J. (2005). La comparaison intersites: une voie pour la recherche en gestion. Québec: Les Presses de l’Université Laval.

Daval, H., Deschamps, B., \& Geindre, S. (2002). Proposition d'une grille de lecture des profils d'entrepreneurs. Revue Sciences de Gestion, 32, 53-74.

Déjean, F., \& Gond, J. P. (2002). La responsabilité sociétale des entreprises: enjeux stratégiques et stratégies de recherche. In Sciences de gestion et pratiques managériales (pp. 389-400). Paris: Economica.

Delchet, K. (2006). La prise en compte du développement durable par les entreprises: entre stratégie et normalisation. Etude de la mise en œuvre des recommandations du guide Afnor SD21000 au sein d'un échantillon de PME françaises. Thèse Ecole des Mines de St-Etienne.

Eisenhardt, K. M., \& Graebner, M. E. (2007). Theory building from cases: opportunities and challenges. Academy of Management Journal, 50(1), 25-32. http://dx.doi.org/10.5465/AMJ.2007.24160888

Evrard, Y., Pras, B., \& Roux, E. (1997). Market - Etudes et recherches en marketing. Paris: Nathan.

Fayolle, A., \& Hernandez, E. M. (2008). Quel avenir pour l'entreprise française?. Revue Humanisme et Entreprise, 288, 53-66.

Fischer, K., \& Schot, J. (1993). Environmental Strategies for Industry. Washington D.C.: Island Press.

Gendron, C. (2004). La gestion environnementale et la norme ISO 14001. Montréal: Les Presses de l’Université de Montréal. 
Gherib Ben Boubaker, J. (2009). De l'efficacité des systèmes incitatifs pour l'engagement des entreprises dans le Développement Durable: cas des entreprises tunisiennes. actes du colloque énergie, changement climatique et développement durable. PS2D, 16-18 June.

Gherib Ben Boubaker, J., Spence, M., \& Ondoua Biwolé, V. (2009). Développement durable et PME dans les pays émergents, entre pro-activité, opportunisme et compromis. Journal of Small Business and Entrepreneurship, 22(3), 355-375.

Gondran, N. (2001). Système de diffusion d'informations pour encourager les PME-PMI à améliorer leurs performances environnementales. Thèse de doctorat en Sciences et Techniques du Déchet, Lyon.

Greening, D. W., \& Gray, B. (1994). Testing a Model of Organizational Response to Social and Political Issues. Academy of Management Journal, 37, 467-498. http://dx.doi.org/10.2307/256697

GTZ MNE. (2006). Synthèse diagnostics environnementaux spécifiques (DES), réalisés dans des entreprises privées tunisiennes en 2003-2006, Tunis.

Gunningham, N., Sinclair, D., \& Burritt, P. (1997). Barriers and Motivators to the Adoption of Cleaner Production Practices. ACEL Final Report, Environment, Australia: Australian Centre for Environmental Law and the Australian National University.

Hemingway, C. (2005). Personal Values as A Catalyst for Corporate Social Entrepreneurship. Journal of Business Ethics, 60, 233-249. http://dx.doi.org/10.1007/s10551-005-0132-5

Hibou, B. (2005). Économie politique de la répression: le cas de la Tunisie. Raisons politiques, 20, 9-36.

Hlady-Rispal, M. (2002). La méthode des cas: application à la recherche en gestion. Perspectives marketing, Bruxelles: De Boeck.

Hofstede, G. (1980). Culture's Consequences: International Differences in Work-related Values. Beverly Hills: Sage Editions.

Hunt, B., \& Auster, E. R. (1990). Proactive environmental management: Avoiding the toxic trap. Sloan Management Review, MIT, Winter.

Institut National des Statistiques. (2005). Répertoire national, Ministère du développement et de la coopération internationale, Tunisie.

Jamali, D., \& Mirshak, R. (2007). Corporate Social Responsibility (CSR): Theory and Practice in a Developing Country Context. Journal of Business Ethics, 243-262. http://dx.doi.org/10.1007/s10551-006-9168-4

Kaptein, M. (2004). Business Codes of Multinational Firms: What do They Say?. Journal of Business Ethics, 50, 13-31. http://dx.doi.org/10.1023/B:BUSI.0000021051.53460.da

Kolk, A., \& Mauser, A. (2002). The evolution of environmental management: from stage models to performance evaluation. Business Strategy and the Environment, 11(1), 14-31. http://dx.doi.org/10.1002/bse.316

Kuhndt, M., Türk, V., \& Herrndorf, M. (2004). Stakeholder engagement: an opportunity for SMEs?. UNEP Industry and Environment, October- December, 40-43.

Lapointe, A., \& Gendron, C. (2004). La responsabilité sociale d'entreprise dans la PME; option marginale ou enjeu vital?. Proceedings of the 7th CIFEPME, Montpellier.

Lauriol, J. (2004). Le développement durable à la recherche d'un corps de doctrine. Revue Française de Gestion, 30(152), 137-150.

Levratto, N. (2009). Les PME - Définition, rôle économique et politiques publiques. Bruxelles: De Boeck.

Luetkenhorst, W. (2004). Corporate social responsibility and the development agenda - a case for actively involving small and medium enterprises. Intereconomics, May-June, 157-166. http://dx.doi.org/10.1007/BF02933583

Madsen, H., \& Ulhoi, J. P. (1996). Environmental Management in Danish Manufacturing Companies: Attitudes

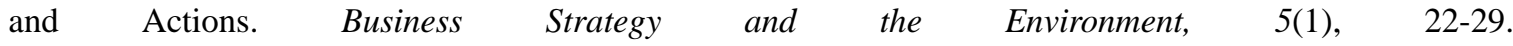
http://dx.doi.org/10.1002/(SICI)1099-0836(199603)5:1<22::AID-BSE39>3.0.CO;2-O

Marais, M., \& Reynaud, E. (2008). Comparaison entre les entreprises françaises publiques et privées face aux exigences du développement durable. Management International, 12(4), 45-64.

Marchesnay, M., Chabchoub Kammoun, S., \& Ellouze Karray, H. (2006). Y a-t-il un entrepreneuriat méditerranéen?. Revue Française de Gestion, 166, 101-118. 
Martinet, A. C., \& Reynaud, E. (2004). Stratégies d'entreprise et Ecologie. Paris: Economica.

MEDD (Ministère de l'Environnement et du Développement Durable). (2006, 2008). Rapport national sur l'état de l'environnement. Tunisie.

Melé, D., Debeljuh, P., \& Arruda, M. C. (2006). Corporate Ethical Policies in Large Corporations in Argentina, Brazil and Spain. Journal of Business Ethics, 63, 21-38. http://dx.doi.org/10.1007/s10551-005-7100-y

Miles, B. M., \& Huberman, A. M. (1991). Analyse des données qualitatives. Bruxelles: De Boeck.

Mucchielli, A. (1991). Les méthodes qualitatives. Paris: PUF.

OTED (Observatoire tunisien de l'environnement et du développement durable). (2007). Industrie Durable. June, Tunisie.

Palpacuer, F., Leroy, M., \& Naro, G. (2010). Management, mondialisation, écologie - Regards critiques en sciences de gestion. Paris: Lavoisier.

Paradas, A. (2006). Perception du développement durable par les dirigeants de petites entreprises: résultats d'enquêtes. Proceedings of the 8th CIFEPME, Fribourg.

Persais, E. (1999). L’adaptation de l'organisation face aux pressions écologistes. Revue Annales des Mines, July, 25-36.

Portugal, E., \& Yulk, C. (1994). Perspectives on environmental leadership. Leadership Quarterly, 5(3-4), 271-276. http://dx.doi.org/10.1016/1048-9843(94)90017-5

Quairel, F., \& Auberger, M. N. (2005). Management responsable et PME: une relecture du concept de responsabilité sociétale de l'entreprise. La Revue des Sciences de Gestion, 40(211-212), 111-126.

Reynaud, E. (2006). Le développement durable au coeur de l'entreprise. Paris: Dunod.

Rice, G. (2006). Pro-environmental Behavior in Egypt: Is there a Role for Islamic Environmental Ethics?. Journal of Business Ethics, 373-390. http://dx.doi.org/10.1007/s10551-006-0010-9

Rondinelli, D. A., \& Vastag, G. (1996). International environmental standards and corporate policies: an integrative framework. California Management Review, 39(1), 106-122.

Russo, M. V., \& Fouts, P. A. (1997). A resource-based Perspective on Corporate Environmental Performance and Profitability. Academy of Management Journal, 40, 534-559. http://dx.doi.org/10.2307/257052

Schneider-Maunoury, G. (2000). Des petites entreprises très vertes. L'Expansion Management Review, March, 77-83.

Scholtens, B., \& Dam, L. (2007). Cultural Values and International Differences in Business Ethics. Journal of Business Ethics, 75, 273-285. http://dx.doi.org/10.1007/s10551-006-9252-9

Shrivastava, P. (1994). Ecocentric leadership in the 21st century. Leadership Quarterly, 5(3-4), 223-226. http://dx.doi.org/10.1016/1048-9843(94)90013-2

Shrivastava, P. (1995). The role of corporations in achieving ecological sustainability. Academy of Management Review, 20(4), 936-960.

Social Consult. (2005). Enquête sur la responsabilité sociale des entreprises en Tunisie. Projet Pacte Mondial, Tunisie.

Spence, L., Rutherfoord, J. R., \& Blackburn, R. A. (1998). Small Business and Environmental Issues in the UK and the Netherlands: A Literature Review and Research Agenda. Small Business Centre, Kingston University, Kingston Upon Thames.

Spence, M., Biwolé, V. O., \& Ben Boubaker Gherib, J. (2007a). Une étude exploratoire du degré d'engagement des PME dans le développement durable. Proceedings of the 10th Scientific Days of the Entrepreneurship Network of the AUF, Antananarivo, 23-26 May.

Spence, M., Gherib, J., \& Biwolé, V. O. (2007b). Développement durable et PME: une étude exploratoire des déterminants de leur engagement. Revue Internationale PME, 20(3-4), 17-42.

Spence, M., Gherib, J., \& Ondoua Biwolé, V. (2011). Sustainable entrepreneurship: Is entrepreneurial will enough? A North-South comparison. Journal of Business Ethics, 99(3), 335-367. http://dx.doi.org/10.1007/s10551-010-0656-1 
Steger, U. (1988). Umweltmanagement, Erfahrungen und Instrumente einer umweltorientierten Unternehmensstrategie. Wiesbaden: Gabler.

Torrès, O. (2001). Les divers types d'entrepreneuriat et de PME dans le monde. Management International, 6(1), $1-15$.

Torrès, O. (2003). Petitesse des entreprises et grossissement des effets de proximité. Revue Française de Gestion, 29(144), 119-152.

Wacheux, F. (1996). Méthodes qualitatives et recherche en gestion. Paris: Economica.

Westerman, J. W., Beekun, R. I., Stedham, Y., \& Yamamura, J. (2007). Peers versus National Culture: An Analysis of Antecedents to Ethical Decision Making. Journal of Business Ethics, 75, 239-252. http://dx.doi.org/10.1007/s10551-006-9250-y

Windatt, E. (1999). Reluctant Followers: Small Companies Pose Special Challenges for Promoters of Voluntary Initiatives. In R. B. Gibson (Ed.), Voluntary Initiatives and the New Politics of Corporate Greening (pp. 149-157). Broadview Press.

Yin, R. (2003). Case Study Research - Design and Methods (3rd ed.). London: Sage.

Zghal, R. (2002). La gestion des entreprises tunisiennes: fondements culturels et défis de la globalisation. in $\mathrm{La}$ Tunisie d'un siècle à l'autre (pp. 189-227). Beit al Hikma.

\section{Notes}

Note 1. Conducted by the ICC Project Coordinator for environment to identify the broad lines of the enterprises' environmental situation, the pre-diagnosis consists of a detailed questionnaire on water, air, noise, waste, security, land and administrative situation with respect to the classified installations.

Note 2. For reasons of convenience of field access, these SMEs were located in the northern regions of France and Tunisia.

Note 3. These SMEs were identified through the authors' contacts with the supporting institutions involved in environmental commitment. 